\title{
Green in times of COVID-19: urban green space relevance during the COVID-19 pandemic in Buenos Aires City
}

\author{
Patricia Laura Marconi ${ }^{1}$ (I) Patricia Eleonora Perelman ${ }^{2} \cdot$ Vanina G. Salgado $^{3}$ \\ Accepted: 13 January 2022 / Published online: 26 January 2022 \\ ( ) The Author(s), under exclusive licence to Springer Science+Business Media, LLC, part of Springer Nature 2022
}

\begin{abstract}
The COVID-19 pandemic has had a deep impact on the way we perceive our world. This study explores its effect on Urban Green Space (UGS) perception in Buenos Aires City (CABA), Argentina. We provide a detailed overview of the distribution of UGS in CABA, along with socio-economic analysis and visitors' profile and perception before and during the restrictive measures adopted by the national authorities to contain the COVID-19 outbreak (July to December of 2020). We conducted a series of surveys based on open and closed questions. Before the pandemic, surveys were carried out in situ in eight parks of six districts, randomly chosen. During the confinement, online surveys were conducted. According to our results, the mean UGS density in CABA is $6.09 \mathrm{~m}^{2} /$ person, but marked differences between districts exist, ranging from $0.02 \mathrm{~m}^{2} /$ person to $17.68 \mathrm{~m}^{2} /$ person. This uneven distribution causes differences in the quality of life of CABA inhabitants, perhaps more pronounced during reduced-mobility situations like COVID-19 confinement. Socio economic analysis were done linking multidimensional poverty, COVID-19 positive cases and urban mobility in CABA. Regarding UGS visitors, before the confinement, the majority of respondents were employees or students; during the confinement, employees and retirees predominated. When asked to choose important attributes to describe their perception about the UGS from a given list, respondents selected "calm," "green," and "sounds of nature," without differences before and during the confinement. However, when asked about the UGS role, the main answer was "a place to be with nature" before the confinement and "an important place in the city" during it. Understanding how society perceives the UGS, especially during crises, is essential to rethink the urban landscape and prepare our cities, towards biophilic cities and for a more sustainable future.
\end{abstract}

Keywords Landscape · Perception · Urban green space · Biophilic cities · COVID-19

Patricia Laura Marconi

marconi.patricialaura@maimonides.edu

Patricia Eleonora Perelman

patriperelman@gmail.com

Vanina G. Salgado

vani.salgado@gmail.com

1 Universidad Maimónides, CONICET, Hidalgo 775, C1405BCJ, TE 4905-1249, Buenos Aires, Argentina

2 Museo Argentino de Ciencias Naturales-CONICET, Universidad de Buenos Aires, CABA, Av. Ángel Gallardo 470(54) (11) 15.3575.9445, Buenos Aires, Argentina

3 División Plantas Vasculares, Museo Argentino de Ciencias Naturales-CONICET, CABA, Av. Ángel Gallardo 470 (54) (11) 15.3575.9445, Buenos Aires, Argentina

\section{Introduction}

Urban green spaces (UGSs) offer visual and aesthetic recreation necessary to provide physical and mental health to big cities' dwellers (Groenewegen et al. 2006). UGSs also provide ecosystemic services important to human welfare. For example, they decontaminate air, reduce rainwater runoff, and mitigate temperature rises by lowering the heat islands generated by concrete from constructed buildings. However, these services are usually underestimated in urban design and environmental management (Schroeder 2009; Ugolini et al. 2020).

Beyond this, humans have an innate connection with nature; Beatley (2011) defines it as "biophilia". Biophilic cities shift the focus of green cities and green urbanism from solely ecosystemic services and environmental conservation to integral human welfare. The city is more than a biodiverse city; it learns from nature, emulates natural 
systems, incorporates natural figures and images to buildings and urban landscape, provides close and daily contact with nature, and seeks to foster awareness of environmental problems and promote the care for the environment. As a result, these cities are sustainable and resilient (Beatley and Newman 2013).

Many authors have emphasized the importance of a friendly environment for urban societies, especially in crisis times (van den Berg et al. 2007; Samuelsson et al. 2020). The COVID-19 pandemic that began early in 2020 has brought up a new appraisal of UGSs (WHO 2020) resignificating them as places for shelter, amusement, and social gathering (CDC 2020a; Baillie 2020; Barrot et al. 2020; Samuelsson et al. 2020; Shoari et al. 2020; Slater et al. 2020; Ugolini et al. 2020). Bailie (2020) analyzed over 40 million posts published through the social network Twitter, and among COVID-19 related tweets; two trend topics were "enjoying nature from home" and "outdoor exercise." Also, images of perfect blue water, deserted city centers, and clear sky appeared more frequently than before. Other studies showed a notable increase in the download of naturerelated cell-phone applications, such as birdwatching apps (Flaccus 2020).

Buenos Aires City (official name, Ciudad Autónoma de Buenos Aires, CABA) is the most populated city in Argentina, with 2,890,151 inhabitants (INDEC 2010). As in the rest of the country, an official resolution known as "Preventive and mandatory social isolation" (in Spanish, Aislamiento social preventivo y obligatorio, ASPO), that basically implied home confinement, was established by Argentine authorities on March 19, 2020 (DNU 297/2020 and modifying clauses 2020). Only those considered essential workers (e.g., health, security, food supply workers) or involved in human care tasks (for children, senior citizens, and persons with COVID-19 risk factors) were allowed to leave their houses. The rest of the inhabitants were allowed to move around a radius of up to $500 \mathrm{~m}$ from their homes exclusively to buy food and essential items. This strict confinement lasted until July 2020. Then, these restrictions were gradually flexibilized and, by October 2020, the local authorities of Buenos Aires City announced permission to practice outdoor physical activities, following the World Health Organization recommendations (2021). When social meetings were finally allowed, UGSs were indicated as the most suitable places to meet relatives and friends. Similar measures and recommendations were adopted in other countries.

Urban green spaces in CABA, including green corridors and other public green areas, occupy 901 ha. They represent an environmental unit, provide similar ecosystemic services, and mitigate environmental impacts (Programa Buenos Aires Verde 2014). The CABA government has launched a program called "Ciudad Verde" ("Green City"), aimed at studying and designing green spaces, and elaborated a series of documents (e.g., Chain 2009; Macri et al. 2011) that specify sustainability criteria for urban design: incorporation of green areas in available spaces, conservation of existing tree specimens, consensus with neighbors by using participative design, among other proposals.

Several studies on environmental perception in Argentina have been published (Faggi et al. 2011; Guida Johnson et al. 2015; Perelman et al. 2012; Madanes et al. 2013; Perelman and Marcon 2016). In the last study mentioned, the public perception of four parks located in CABA (Saavedra, Avellaneda, Centenario, and Micaela Bastidas) was assessed. This study resumes that research, adding more parks, deepening on the demographic analysis and revealing the revalorization that UGSs experienced during the COVID-19 pandemic.

\section{Methodology}

Different terminology has been applied formally and informally to the population mobility restrictions implemented to prevent COVID-19 spread. Since the terms quarantine and isolation apply to instances where the person has been infected or exposed to the disease (CDC 2017) we utilize the terms "confinement" for the strict confinement period (March to July 2020) and "distancing" for the subsequent more flexible measures adopted by the government (August 2020 to January 2021) as described in the introduction.

\section{Demographic assessment and people's mobility analysis}

For administrative purposes, Buenos Aires City (Ciudad Autónoma de Buenos Aires, CABA) is divided into 15 districts (specific Spanish name: "comuna"). We analyzed the inhabitants' density and the surface corresponding to the urban green space at district levels and the whole city. The analysis was carried out using data supplied by Dirección General de Estadísticas y Censos, GCBA (Estadísticas GCBA 2019b).

People's mobility during the confinement was analyzed based on data obtained from Google (2021) and Apple (2020). Google carries out strategic surveys with datasets gathered from worldwide users, who enable localization through their cell phones. The mobility occurring each day was compared with a baseline constructed with the reference values obtained for the same day of the week from January 3 to February 6, 2020. Also, the changes in duration of a mobile in one place (Residential) were evaluated.

Apple obtains information from data collected through its iPhone users and can differentiate between those displacing by vehicle or on foot; it also compares these profiles with 
that shown by a baseline generated from values obtained before the confinement.

To evaluate socio-economic factors the multidimensional poverty index was used (MDP). This index is a measure of homes with concrete deficiencies in determinate goods, services and activities considered necessary for a dignified life in Buenos Aires City. It evaluates 17 indicators grouped in five basic dimensions: food, health and care assistance, living space and services, home equipment, and social and educational deprivation. A home is considered deprived of one of these dimensions if it lacks at least $33 \%$ of the composing indicators for that dimension, and it is considered multidimensionally poor if it is deprived of at least two of the five dimensions (Estadísticas GCBA 2019b).

Confirmed cases of Covid -19 during 2020 for each CABA district were obtained from official statistics (BADATA 2020).

\section{UGS perception surveys}

We selected six districts randomly and chose eight parks located at them: Parque Avellaneda (district 9), Parque
Chacabuco (district 7), Parque Centenario (district 6), Parque Leonardo Pereyra (district 4), "Parque Lezama (district 1), Parque Micaela Bastidas (district 1), Parque Rivadavia (district 6), and Parque Saavedra (district 12) (Fig. 1). These parks represent $27 \%$ of the urban green space in CABA (99.9 ha) and are categorized as "big parks." During springs and winters comprised in the period 2012-2018, we surveyed 60 adult visitors per visit, park, and year, chosen randomly during each visit following Cochran and Cox (1965) methodology. After the end of the strict confinement, during the social distancing period (December 2020-January 2021), surveys (298) were performed through online questionnaires (using Google Forms) and distributed initially among the authors' personal and professional networks (email, WhatsApp) and later posted on Facebook groups. Participants were kindly requested to distribute the survey to their contacts. All respondents participated voluntarily and answering the survey implied their consent to participate in this research.

Surveys included open and closed questions divided into two sections: A and B. Section A covered social and demographic data such as age, gender, education level, and

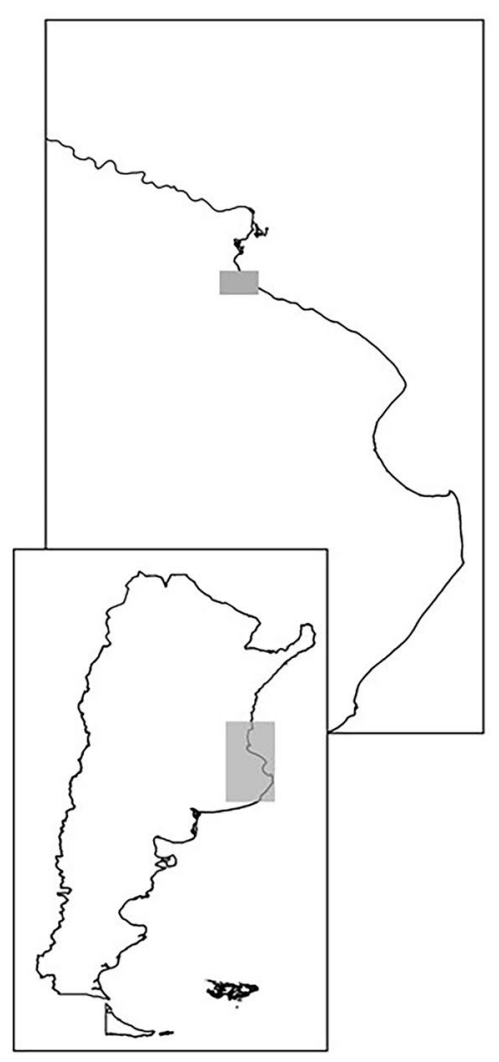

Fig. 1 Buenos Aires Autonomous City in Argentina. Districts ("comunas") are indicated by numbers. Arrows indicate parks selected for surveys (A: Avellaneda; $\mathrm{CH}$ : Chacabuco; CE: Centenario; LP; Leonardo Pereyra; L: Lezama; MB: Micaela Bastidas; R:
Rivadavia; S: Saavedra) MDP \% is indicated by gradient of roses. Green is indicative of Urban Green Space. Blue is indicative of inaccessible UGS: population with UGS within a "10 min' walk" distance ( modified from Vazquez Brust and Rodriguez 2020) 
Table 1 Landscape attributes included in the survey, according to the classification made by Vouligny et al. (2009)

\begin{tabular}{lll}
\hline & Category & Attribute \\
\hline Experiential & atmosphere & calm, greatness, comfortable space \\
& admiration & peace, beauty, harmony \\
& sensorial/ & sounds of nature, water, horizon, extension, landscape \\
& colours/ & colours, green \\
Experimental & scenery & nature, animals \\
& maintenance & healthy, secure and protected, clean and well- \\
& maintained, patrimony conservation \\
\hline
\end{tabular}

occupation. Answering these questions was optional. Section B focused on the perception that inhabitants have about the UGS: this included three questions about the frequency of visiting UGSs and distance to reach them, and five questions focus on people's perception, the reason for the visit, and significance of UGSs. Answering these questions was mandatory.

In section $\mathrm{B}$, respondents had to choose three words out of a list of 20 to define UGS (Table 1). The list included words or expressions describing experimental and experiential attributes (Vouligny et al. 2009). Experimental attributes refer to the cognitive and physical evaluation made by the park visitor such as "birdsongs," "leaves' colours," or "importance as city patrimony." Experiential attributes refer to how individuals perceive the environment as a whole and define their emotions and expectations, such as "calm," "peace," or "harmony" (Vouligny et al. 2009).

\section{Statistical analysis}

Quantitative variables were analysed using the F test, and univariate and multivariate analysis was performed to detect relationships between them. Binary variables (e.g., Yes/No) were transformed into numbers (0/1). Relative frequencies were calculated in percentages and analyzed with the Chisquare test.

We performed a correspondence analysis to detect associations among variables. Data arrays were constructed by combining gender, closeness to the park, attribute selected,
Fig. 2 Buenos Aires City inhabitants and urban green space. a: Total density; b: UGS per inhabitant. Arrows indicate the districts where surveys before the confinement were conducted

\section{density (inhabitant/km²)}

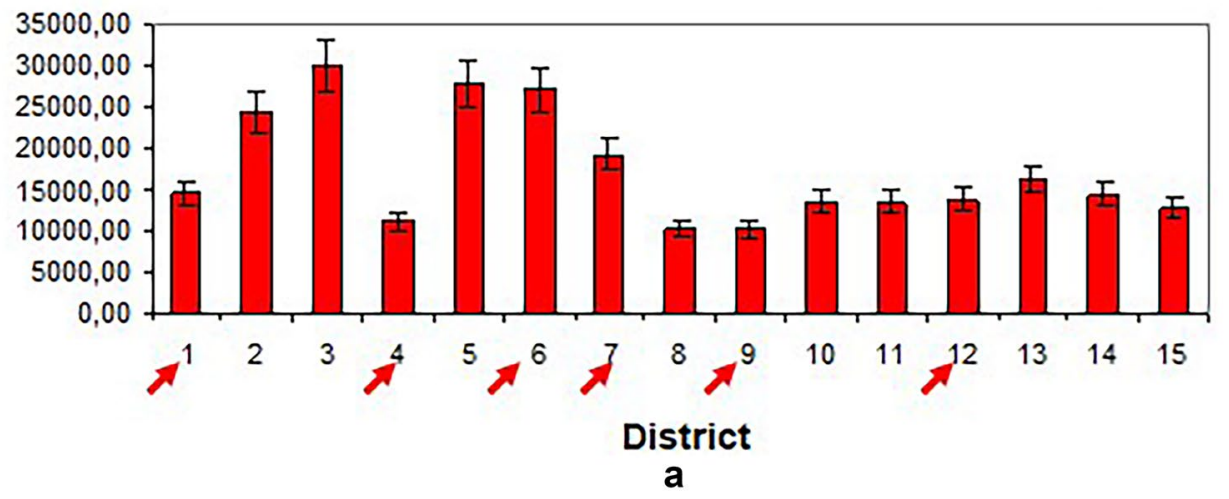

$\mathrm{m}^{2}$ green/inhabitant

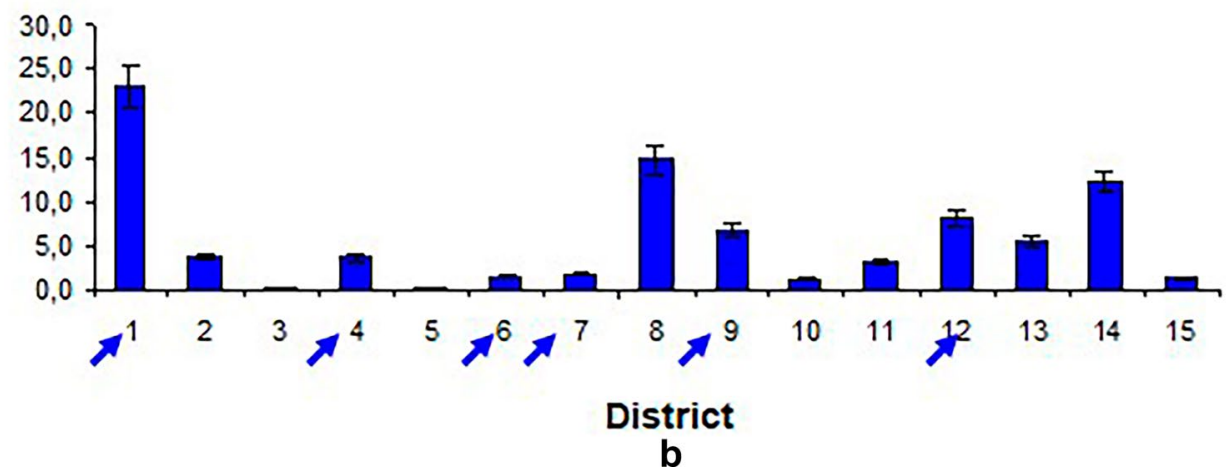


Fig. 3 Differential accessibility to urban green space in two CABA districts. In grey: UGS influence area in (a) district 1 and (b) district 6, calculated as a $500-\mathrm{m}$ perimeter or a $250-\mathrm{m}$ perimeter around parks and squares, respectively

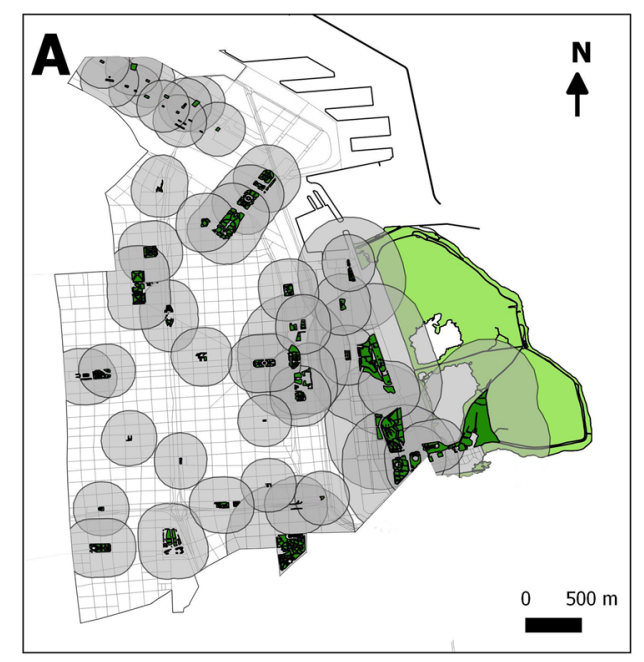

and park. The Euclidean distance was used as a similarity index. Principal component analysis was used to identify modes of variation in functional data and canonical correlation analysis to make inference based on the cross covariance matrix of multiple datasets. Results were analyzed with InfoStat ${ }^{\circledR}$ software.
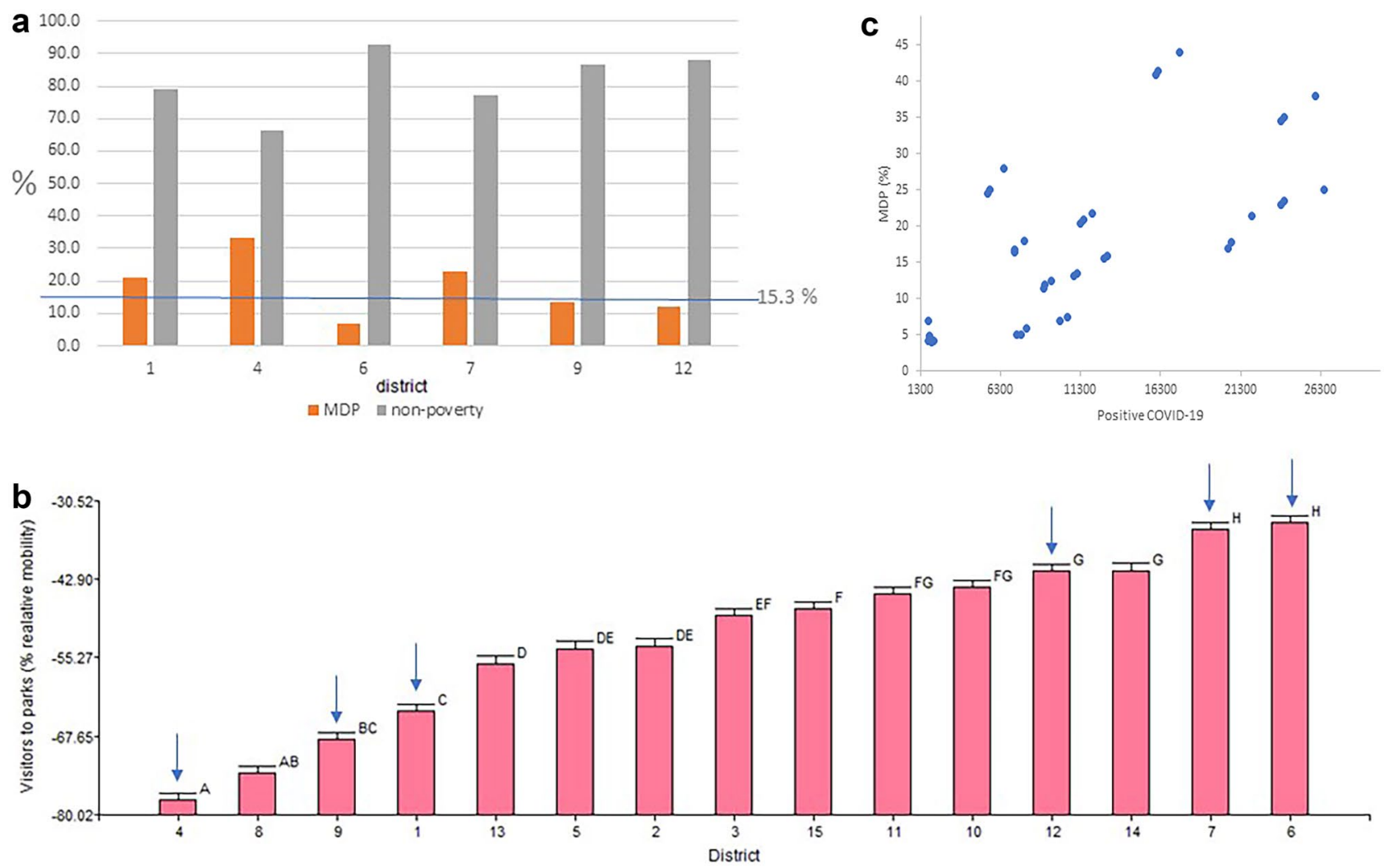

Fig. 4 Socio economic analysis: (a) Percentage of MDP and their counterpart (MDnon-P), line shows the average of CABA; (b) Correlation between COVID-19 positive cases and MDP; (c) Frequency

of visitors to parks (Google 2021), arrows indicate the districts where surveys were conducted 


\section{Results and discussion}

\section{Demographic background and mobility analysis}

Urban green space density in cities is a dynamic process and changes over time. In CABA, this value changed from 6 $\mathrm{m}^{2} /$ person in 2006 to $5.9 \mathrm{~m}^{2} /$ person in 2014, representing a loss of $1.66 \%$, and then increased to $6.09 \mathrm{~m}^{2} /$ person in 2018 (Estadísticas GCBA 2019a). Along the period covered by our analysis, the mean density of UGS in CABA was 6.3 $\mathrm{m}^{2} /$ person. In some districts, UGS decreased. For example, district 1 diminished the UGS density from $24.6 \mathrm{~m}^{2} /$ person in 2009 to $22.9 \mathrm{~m}^{2} /$ person in 2014 and district 8 from $23.1 \mathrm{~m}^{2} /$ person in 2011 to $14.7 \mathrm{~m}^{2} /$ person in 2014. During the same period, other districts such as 13 and 14 increased their relative participation in CABA UGS (11\% and 38\%, respectively).

UGS distribution in CABA is heterogeneous, ranging from $22.9 \mathrm{~m}^{2} /$ person in district 1 to $0.2 \mathrm{~m}^{2} /$ person in district 5. There is an inverse relationship between the number of inhabitants and the UGS density (Fig. 2). Districts 5 and 6 are densely populated, with high buildings or numerous small habitational units, and have low UGS area per person. This was also observed in districts 2, 3, and 7. Districts 9 and 12 are less populated, with an array of houses and mediumsize buildings (Fig. 2a), and show a greater UGS area per person (Fig. 2b).

The highest UGS densities correspond to districts 1, 8, and 14. District 1 constitutes a special case, as it includes the protected area called "Reserva Ecológica Costanera Sur," which covers 350 ha, the financial area of the city, and the exclusive neighborhood "Puerto Madero," a relatively recent (20-25 years) urbanization with inhabitants of high socioeconomical level, offices, and restaurants. These three areas have very few permanent residents. The combination of the additional green space and the low number of permanent residents results in a high UGS density per person $\left(22.9 \mathrm{~m}^{2} /\right.$ person).

Districts 8 and 14 have a lower UGS density than district $1\left(14.7 \mathrm{~m}^{2} /\right.$ person and $12.1 \mathrm{~m}^{2} /$ person, respectively), without significant differences between them (Fig. 2b). District 8 contains large public, open spaces like "Parque Indoamericano," the municipal racetrack, and many public buildings, among other uninhabited large areas.
Table 2 Urban green space distribution and people's mobility. Data obtained from Google (2021)

\begin{tabular}{llll}
\hline District & $\begin{array}{l}\text { Green space } \mathrm{m}^{2} / \\
\text { person }\end{array}$ & $\begin{array}{l}\text { Surveyed area } \\
(\%)\end{array}$ & $\begin{array}{l}\text { Mobility } \\
\text { in UGS } \\
(\%)\end{array}$ \\
\hline 1 & 22.9 & 7.1 & -60.9 \\
4 & 3.7 & 7.1 & -51.8 \\
5 & 1.5 & 13 & -41.1 \\
7 & 1.8 & 17.6 & -32.3 \\
9 & 6.8 & 37 & -59.4 \\
12 & 8.1 & 11.3 & -48.3 \\
CABA & 5.8 & 100 & -31 \\
\hline
\end{tabular}

The rest of the districts have UGS densities lower than $8 \mathrm{~m}^{2} /$ person. District 6 has a density of $1.5 \mathrm{~m}^{2} /$ person, 15 times lower than district 1 (Fig. 2b). Districts 3, 5, 10, and 15 have UGS densities close or even under that necessary to maintain social distance. In a hypothetical scenario in which all citizens attend to these UGSs at the same time, as mentioned by Shoari et al. (2020), adequate social distancing would not be met.

In districts 1 and 6 , parks are close to each other. This generates an overlap in their influence areas and causes differential accessibility to the various UGSs within these districts. Thus, people living within the overlapping influence area have easier accessibility to the green space than people living outside this area (Fig. 3). This heterogeneity in UGS distribution and accessibility is repeated throughout the city (Fig. 1). It is a common trait in old cities like Buenos Aires and has been observed in previous studies conducted in other countries (Shoari et al. 2020).

From the socio-economic perspective, CABA measures multidimensional poverty (MDP) continuously since 2019 . According to this index, by the end of $2019,15.3 \%$ of all homes and $25.7 \%$ of homes with children under 18 years of age were poor in CABA (Estadísticas BA 2019b, Fig. 4A). Figure 1 shows the MDP geographical pattern in CABA and, specifically, in the districts analyzed in this study. In the north and center of the city (districts 6 and 12), MDP is, at least, five points below the city's average $(20,3 \%)$; in the south, it reaches the highest score $(43 \%$, district 4$)$ and in the center, MDP is closest to the average (communes 1, 9 and 7). This tendency is repeated throughout the city (Fig. 4A, B).

Table 3 Educational level of respondents before and after confinement. Pre-conf., pre-confinement; Conf., confinement. Significant differences (Tukey test, $p<0.05$ ) among districts or within districts are indicated by Capital letters and asterisks, respectively

\begin{tabular}{|c|c|c|c|c|c|c|c|c|}
\hline Education / district & 1 & 4 & 6 & 7 & 9 & 12 & Pre-conf & Conf \\
\hline Elementary & $37 * \mathrm{~A}$ & $24.1 \mathrm{~B}$ & $7.4 \mathrm{~A}$ & $14.8 \mathrm{~A}$ & $24 \mathrm{~A}$ & $7.4 \mathrm{~A}$ & $7.75 \mathrm{C}$ & $0.3 \mathrm{C}$ \\
\hline High School & $57.4 \mathrm{C}$ & $75.9 \mathrm{C}^{*}$ & $44.4 \mathrm{~B}$ & $64.8 \mathrm{C}$ & $26 \mathrm{AB}$ & $35.2 \mathrm{~B}$ & $34.25 \mathrm{~A}$ & $13.4 \mathrm{~B}$ \\
\hline University & $40 \mathrm{~B}$ & $11.1 \mathrm{~A}$ & $50 \mathrm{BC} *$ & $25.9 \mathrm{~B}$ & $50 C^{*}$ & $59.3 C^{*}$ & $13.5 \mathrm{~B}$ & $86.3 \mathrm{~A}$ \\
\hline
\end{tabular}


Fig. 5 Demographics. (a)

Profile of surveyed people; (b)

Visit frequency; (c) Conglomer-

ate analysis for occupation and

visit frequency
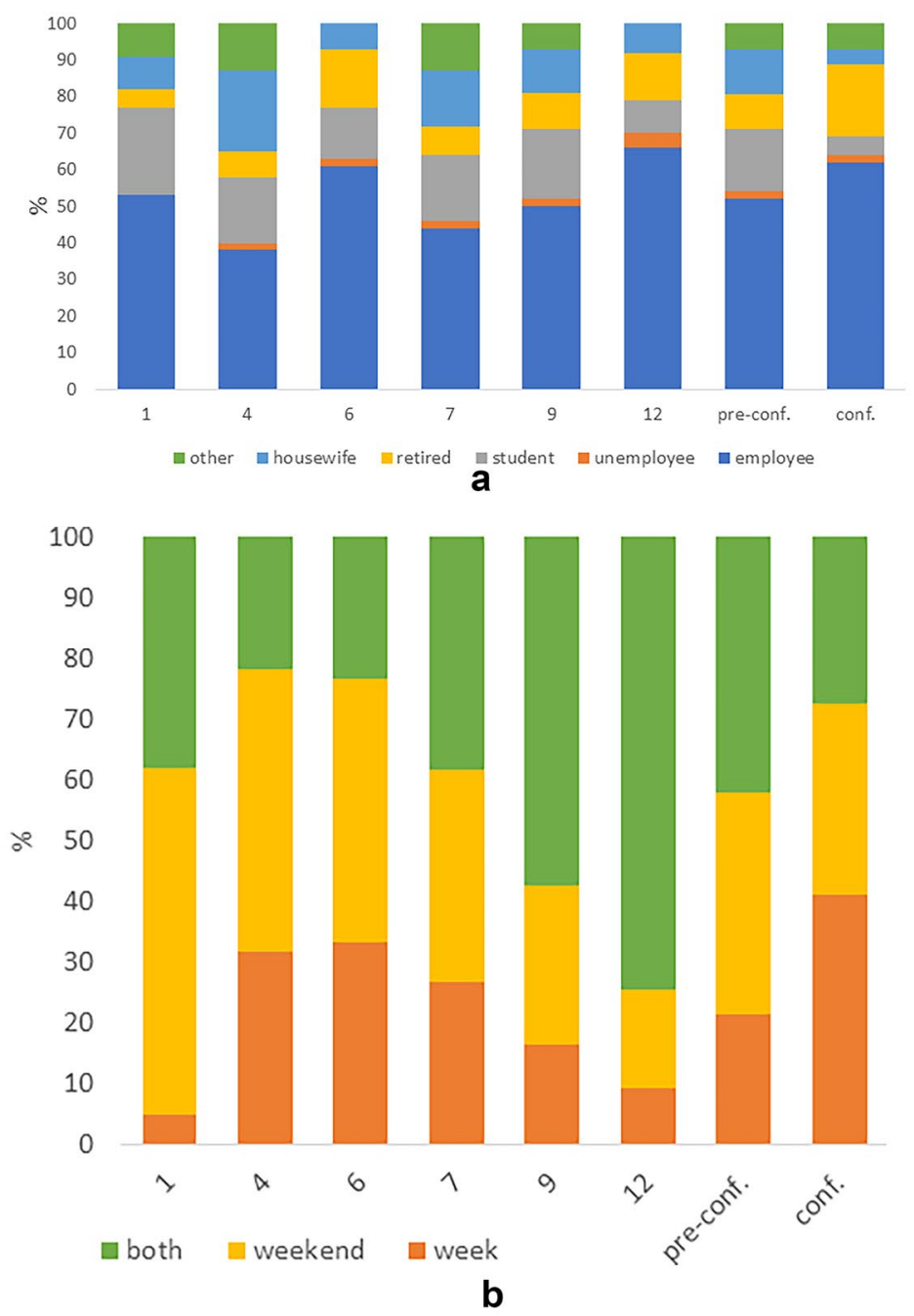

Promedio (Average linkage)

Distancis: (Euclides)

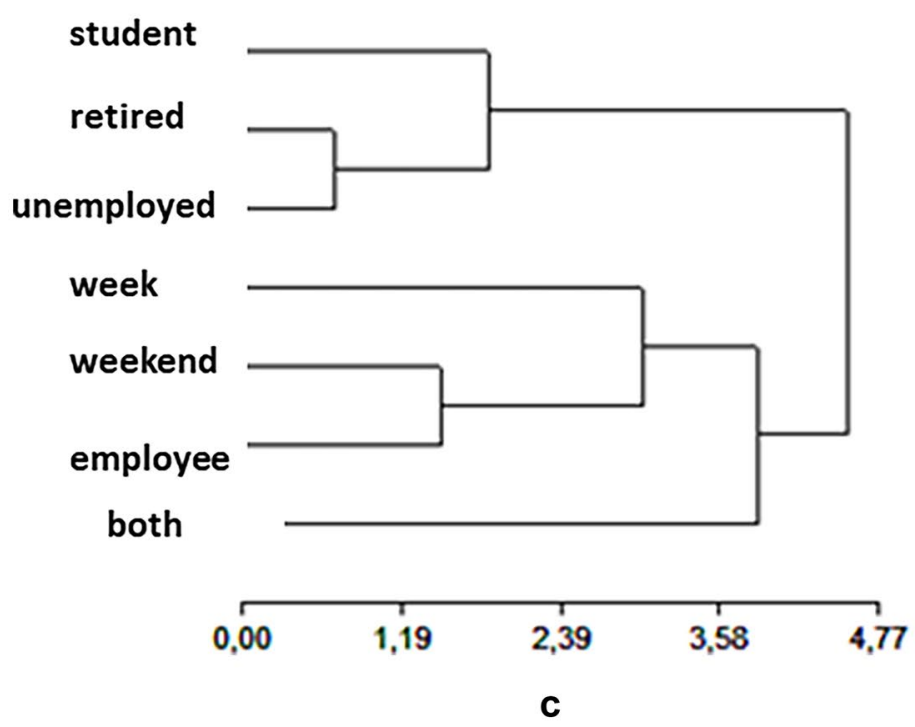


People in acute multidimensional poverty are a high-risk group for COVID-19. Factors associated with this condition like malnutrition, lack of access to drink water, inadequate sanitation (lack of sewer and storm drain), among others, cause them to be unable to reach the recommended preventive social isolation measures (Alkire et al. 2020). According to OPHI (2020) unsafe drinking water is associated with weakened immune systems (WHO 2020; UNICEF 2019). Malnutrition is strongly associated with weakened immune systems, morbidity, and mortality - particularly among young children. These indicators are connected with a highest risk of contracting and spreading COVID-19 (Lustig and Tommasi 2020). In that respect,we observed a positive correlation between MDP and COVID-19 cases (Fig. 4C). As expected, districts with high numbers of COVID-19 positive cases also have a high percentage of homes in MDP (positive canonic correlation; $\mathrm{R}^{2}=0.49$ y $\mathrm{L}=-0.046$ for $p<0.0001$ ). However, district 1 had the highest proportion of COVID19 cases in 2020. This district has both the highest UGS per person percentage and the lowest MDP percentage (Figs. 2 and 4A, B). We did not find a positive correlation between MDP and UGS per person in the evaluated districts (PCA; $\mathrm{R}^{2}=0.018$ y $\mathrm{L}=0.16$ for $p<0.01$ ), but in southern and central districts the heterogeneous distribution of the UGSs causes large areas in which they are further than a ten minutes walking distance and thus considered unavailable (Figs. 1 and 3) (Vazquez Brust and Rodriguez 2020).

During the strict confinement period, which lasted from March 2020 to July 2020, visits to UGS decreased by about $87 \%$. When attending UGSs to practice physical activity was allowed, people visiting UGSs increased, reaching a level $45 \%$ below the baseline. Highly populated districts with low UGS densities (e.g., districts 6 and 7) showed the highest mobility rates. As expected, district 1 , which includes the financial district and the historical center, showed the lowest mobility rate (Table 2) (Google 2021). Regarding how people mobilized, mobility on foot decreased by $81 \%$ and by vehicles $69 \%$ compared to the baseline during the strict confinement and slightly recovered during the last months of 2020 to reach values of $66 \%$ and $43 \%$ under baseline levels, respectively (Apple 2020).

Also, mobility analysis showed that districts (4 and 9) with the highest MDP attendance to parks decreased while districts from the north of the city (12 and 6) showed high mobility (Table 2 and Fig. 4B). Multivariate analysis using the mobility by residential zone as cofactor showed that District 1 had a significant reduction to park attendance which probably responds to the low amount of residents of the district since it is a mostly touristic and financial area $(p<0.0001$, Figs. 2 and 4B). Contrary to expected, district 9 , in the city center, presented low mobility rates and district 7, which has a high MDP percentage, showed high mobility rates (Figs. 2 and 4B).

\section{UGS perception surveys}

The final sample consisted of 1740 surveys, including the in situ surveys conducted in the parks before the confinement and the online questionnaires obtained during the confinement and distancing periods.

\section{Section A. Social and demographic data}

Most respondents were female $(66.8 \%$ before the confinement and $76.3 \%$ during it), with diverse education levels and occupations (Table 3). Almost half of the respondents before the confinement had a high school diploma (47.9\%). A trend for higher education levels was detected in districts 6, 9, and
Fig. 6 Activities done in a special sector (i.e. playground for kids, emblematic area, gym equipment, the lake area, among others) vs. general uses of the UGS in surveyed districts.

Conf., confinement

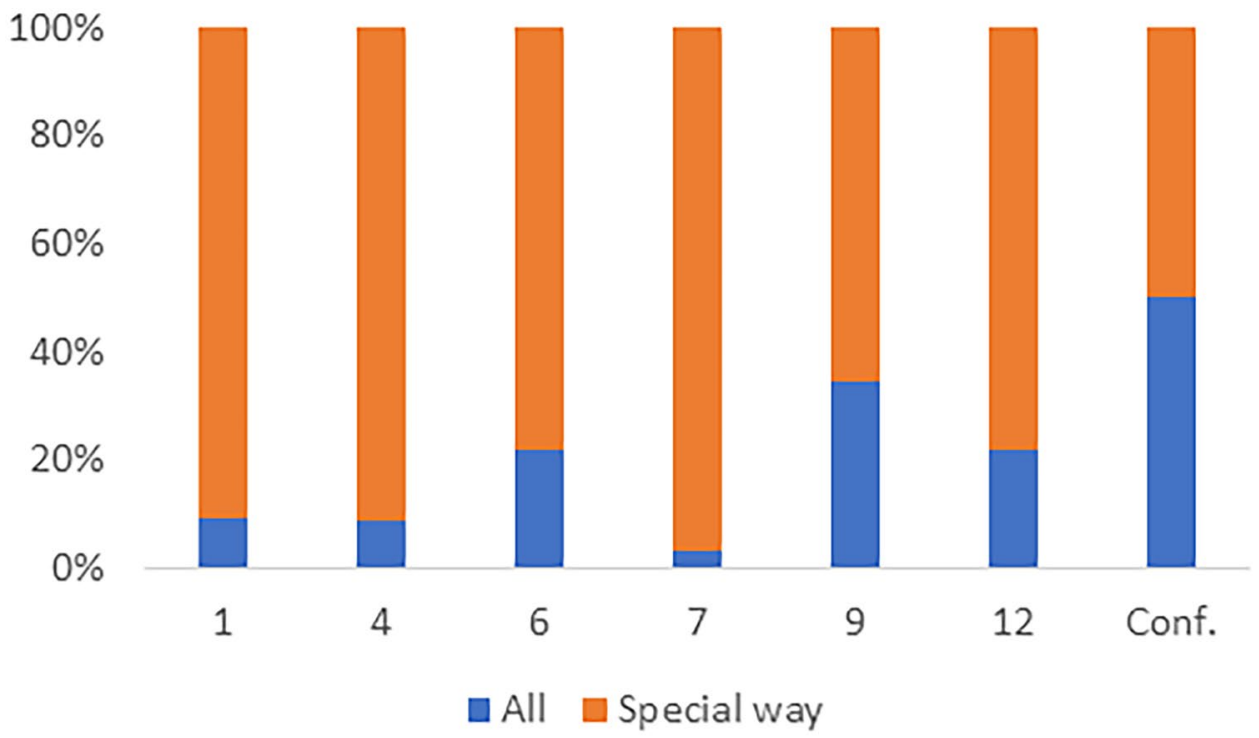


Table 4 Meaning of urban green space. Conf., confinement

\begin{tabular}{lrlrcccrc}
\hline & parks & unknown & important & fresh air & nature & recreation & outdoor & calm \\
\hline 1 & 20.9 & 0.0 & 9.3 & 9.3 & 37.2 & 9.3 & 7.0 & 7.0 \\
4 & 7.4 & 5.6 & 20.4 & 14.8 & 37.0 & 3.7 & 11.1 & 0.0 \\
6 & 9.9 & 1.4 & 4.2 & 12.7 & 42.3 & 9.9 & 12.7 & 7.0 \\
7 & 17.5 & 1.6 & 17.5 & 12.7 & 27.0 & 11.1 & 3.2 & 9.5 \\
9 & 46.2 & 0.0 & 15.4 & 0.0 & 23.1 & 7.7 & 7.7 & 0.0 \\
12 & 50.9 & 0.0 & 3.8 & 1.9 & 17.0 & 9.4 & 13.2 & 3.8 \\
conf & 6.5 & 0.0 & 34.9 & 13.4 & 25.7 & 11.6 & 3.8 & 4.1 \\
\hline
\end{tabular}

12 and for lower (elementary school) in district 1 (Table 3 ). During the confinement, most respondents were university students or graduates. This could be due to a methodological bias, as online surveys required at least basic internet knowledge and computer skills to participate.

Data showed homogeneity regarding respondents' occupation. Most respondents were employees (52\% before the confinement and $62 \%$ during the confinement). In the surveys conducted before the confinement, district 4 showed the lowest employee proportion (38\%) and the highest housewives relative weight (22\%). In district 7 , the highest students' percentage (21.4\%) was found, and in district 12 , the lowest. Students' overall participation in the surveys was significantly lower during the confinement $(5 \%)$, and this was probably related to the online education imposed by COVID-19 prevention regulations. Retirees represented $11.6 \%$ of all respondents before the confinement, with the highest record for retirees' participation in district 6; this value rose to $19.2 \%$ during the confinement. Before and during the confinement, the unemployed population was under $5 \%$ (Fig. 5A).

Most respondents (80-100\%) declared visiting UGSs in several opportunities both before and during the confinement regardless of social and demographic status. Regarding day of the week for UGS attendance, (Fig. 5B) respondents in district 1 showed a clear preference for visiting parks on weekends, which can be explained by the proximity of the protected area "Reserva Ecológica Costanera Sur" and the touristic area. No preference between weekdays and weekends was detected among respondents surveyed in districts 9 and 12. Students, unemployed, and retirees visited parks both on weekdays and weekends. Employees chose weekdays when the UGS was near their workplaces and weekends when they were near their homes. During the confinement, respondents declared visiting UGSs irrespective of the week's day but reported a preference for afternoon visits (53.1\%; data not shown).

During the confinement, $98.3 \%$ of the respondents visited UGS at least once, and most of them several times. Visits' duration varied: half an hour $(22.9 \%)$, one hour $(43.5 \%)$, and more than two hours (21.6\%). When the question was "Who did you visit UGS with?" surprisingly, the majority of respondents answered "alone" (29.8\%), even though UGSs were the recommended places for social gathering. Respondents also visited UGS "with friends" (21.6\%) and "with family" (19.9\%), without significant difference between these three answers. Given the mobility restrictions, most of the respondents visited UGS located near their homes (70\%).

Regarding the usage of the UGS, before confinement visitors tended to use specific parts of the park while during
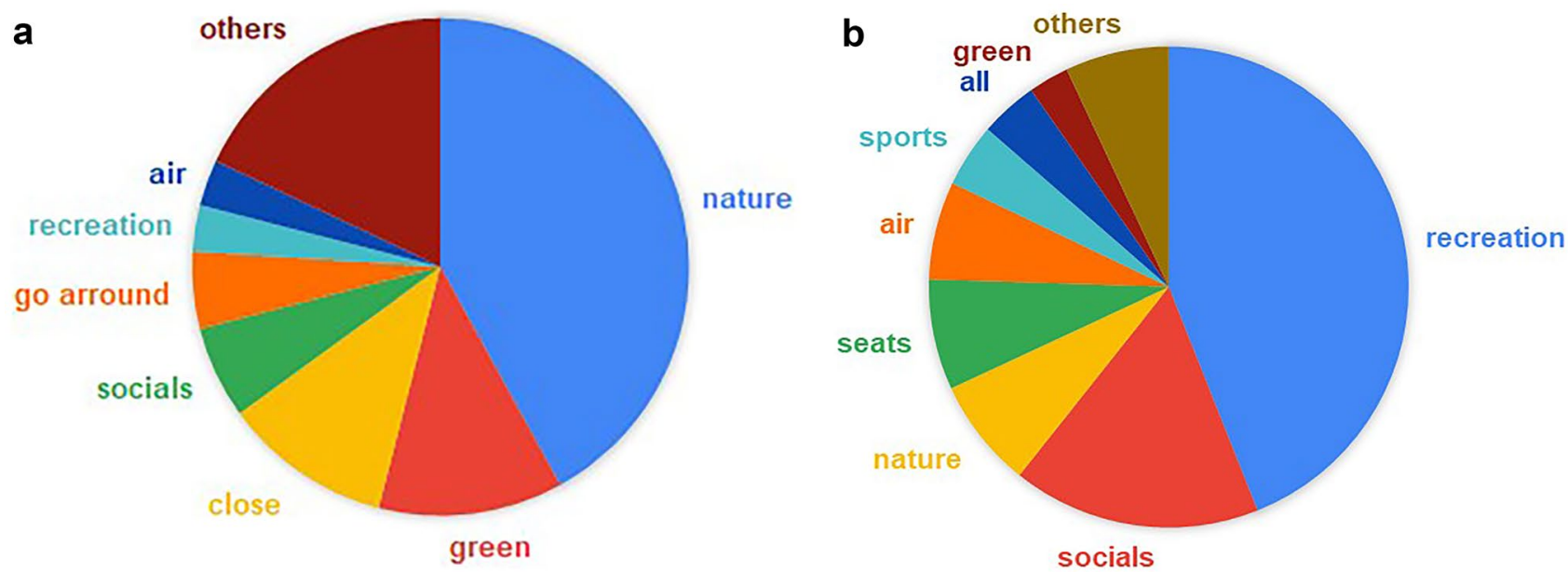

Fig. 7 UGS perception during the COVID-19 confinement. (a) Reason for visiting; (b) Services provided by UGS 
Table 5 UGS perception (\%). Significant differences within the countries were identified by the Chi-square test between coupled options

\begin{tabular}{|c|c|c|c|c|c|c|}
\hline \multirow[b]{2}{*}{ District / Attribute } & \multicolumn{3}{|c|}{ Experimental } & \multicolumn{3}{|l|}{ Experiential } \\
\hline & $\overline{\text { Calm }}$ & Harmony & $\overline{\text { Beauty }}$ & Sound of nature & Green & Nature \\
\hline 1 & 20 & 7.5 & 13 & 9 & 16.5 & 12 \\
\hline 4 & 28 & 8 & 13 & 11 & 20 & 11 \\
\hline 6 & 27 & 14 & 7 & 8 & 9 & 7 \\
\hline 7 & 11 & 8 & 17 & 2 & 1 & 18 \\
\hline 9 & 9 & 3 & 6 & 6 & 4 & 4.5 \\
\hline 12 & 10 & 2.5 & 2 & 5 & 9 & 3 \\
\hline Confinement & 14.1 & 4.2 & 4.9 & 11.6 & 18.3 & 10.9 \\
\hline
\end{tabular}

confinement no specific area was chosen (Fig. 6). This could be explained by visitors' tendency to attend the parks alone (29.8\%) causing them to wander through the space rather than stay in one place. This shows that the pandemic had effects in the way in which UGSs are used.

\section{Section B. Perception of UGS}

When asked for the meaning of urban green space in the surveys conducted before the confinement, respondents associated it with "a place to be in contact with nature" as the predominant answer or "parks of the city," in second place. In districts 9 and 12, the order of these answers was inverted. During the confinement, respondents associated urban green space with "something important" or, significantly less chosen, "a synonym of nature" (Table 4). Before the confinement, only a reduced proportion of respondents (11\%) regarded UGS as "something important."

Concerning the reasons for visiting UGS during the confinement, the choices were "to be in contact with nature" $(42 \%)$, "to see green" (12\%), or "because it is close to home"

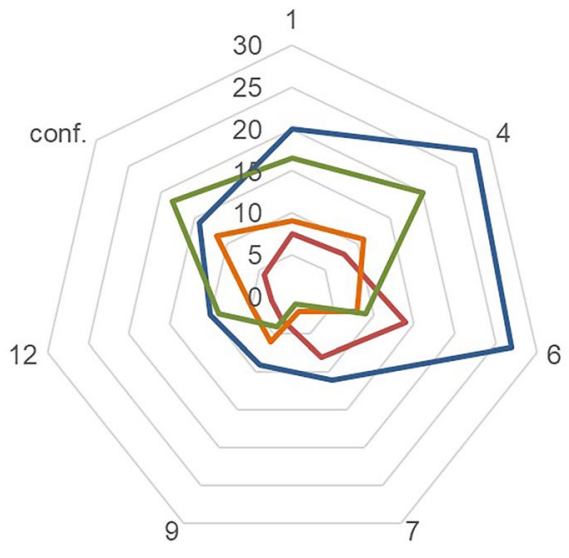

-Calm - Harmony - Sounds of Nature - Green

Fig. 8 Attributes assigned to UGS with high frequency
(11\%). When inquired about the services provided by UGS, answers were related to "recreation" (44\%) and "social gathering" (14\%), even though "socialize" was seldom chosen as a reason for visiting green spaces (Fig. 7).

Before the confinement, when asked to choose three attributes to describe the perception of UGS (out of 20, Table 1), respondents chose the experiential attribute "calm" as the most relevant, followed by "green" and "sounds of nature," both experimental attributes. In districts with high population density (i.e., districts 4 and 6), "calm" reached the highest score. During the confinement, the tendency was inverted, and respondents chose mainly the experimental attribute "green" (18\%), followed by "calm" (14\%) and "nature" (11.6\%) (Table 5 and Fig. 8).

\section{Conclusions}

Living conditions such as accessibility to UGS, housing, and socio-economical conditions, affect daily life and, to some extent, determine how groups within a society cope with the COVID-19 pandemic (Vlahov et al. 2007). For example, some recent studies conducted in the United States show that living in small apartments with several occupants in highly populated neighbourhoods predisposes the Afro-American community to acquire SARS CoV-2 (CDC 2020b; Yancy 2020). In addition to the serious risk that this disease poses on physical health, many studies have related social confinement and distancing (measures widely implemented to reduce COVID-19 propagation) with feelings of loneliness, depression, post-traumatic stress disorder symptoms, confusion, rage, and frustration (Al Sulais et al. 2020; Brooks et al. 2020; Giallonardo et al. 2020; National Academic of Sciences, Engineering, and Medicine 2020; Tee et al. 2020; Samuelsson et al. 2020; Serafini et al. 2020 Saurabh and Ranjan 2020). In particular, this study presents information on the structure of UGS in Buenos Aires City and its impact on Buenos Aires inhabitants' perception of these green areas before and during the confinement implemented to reduce COVID-19 propagation. 
For the past six years, the surface covered by UGS in Buenos Aires City remained stable at about $6.3 \mathrm{~m}^{2} /$ person, a value which is nearly at half of that recommended by the World Health Organization (2020): 10 to $13 \mathrm{~m}^{2} /$ person. In addition, UGS is unevenly distributed, as expected, given CABA's ancient structure. Buenos Aires (under the official name of "Nuestra Señora Santa María del Buen Ayre") was founded in 1536 and expanded considerably at the end of the nineteenth century in a rather unplanned manner, far away from current urbanization politics (WHO 2020).

Also, over half of the population (52\%) are senior citizens who live alone. Only $1.3 \%$ of the inhabitants share their homes totaling three or more occupants (Estadísticas GCBA 2019a). Particularly senior citizens living alone experienced psychological problems derived from the pandemic deepening (Alomo et al. 2020; Ceberio 2020; Sorbara et al. 2021; Camarotti et al. 2020). In contrast, in houses with several occupants, where close contact becomes unavoidable, the risk of infection increases. Whether to maintain safe confinement or prevent SARSCoV-2 propagation, UGSs became crucial to safely practice physical activities and recover social interactions. Under these circumstances, can the UGS perception be transformed?

Humans' appraisal of the landscape results from the perception of the surroundings and the individual preference for nature, in contraposition with the urban pattern. This has already been described in pioneer studies in the field, such as that of Appleton (1975), Purcell and Lamb (1998) and Maulan et al. (2006), and also observed in some preliminary studies carried out by our group (Perelman and Marconi 2016).

We detected that survey respondents of varied social and demographic status assigned similar meaning to UGSs before and during the COVID-19 confinement, recognizing them as calm and natural landscapes, with abundant vegetation and nature sounds. The UGS meaning was considered as "an important place in the city" only during the confinement. This indicates that the COVID-19 pandemic can be a starting point to rethink the city's landscape and its role in life quality. It is important to point out that internet-based technologies were crucial to analyze the actual scenario without breaking the imposed confinement. However, these tools rely on participants who can manage computers or other electronic devices and technologies, generating a potential bias. Our results show that survey respondents visited UGSs located close to their homes, more than once, and alone or with family or friends.

Accessibility to UGS is important under normal conditions and even more during a pandemic. It is vital to address the limitation that heterogeneous access to UGS represents, preventing citizens from their recognized benefits. Large cities like Buenos Aires need to distribute UGS in a more homogenous way, avoiding areas with extreme population densities, networks of overpopulated streets, and mono-functional neighborhoods. It is also important to provide access to integrated spaces for both social interaction and secluded relaxation (Samuelsson et al. 2020).

UGS in Buenos Aires Autonomous City were proven important for citizen's well being before and during the pandemic and will continue to be so in the post-pandemic world. To provide its citizens with a better quality of life resourceful, capital, densely populated cities like CABA have both the challenge and the potential to become biophilic cities as described by Beatley (2011). In this context, understanding public perception of UGS is mandatory to raise awareness about its relevance for urban landscape and the necessity to encourage UGS conservation and promotion as part of public policies.

Acknowledgements Authors would like to thank student Andrea Vidmar for her collaboration.

Authors' contributions All authors read and approved the final manuscript.

Funding Without funding resources.

Availability of data and material The datasets used during the current study are under CONICET guard and, also, they are available from the corresponding author on reasonable request.

\section{Declarations}

Ethics approval and consent to participate Not applicable

Consent for publication The authors gives the permission to publish the work.

Competing interests The authors declare that they have no competing interests.

\section{References}

Alkire S, Dirksen J, Nogales R, Oldiges C (2020) Multidimensional poverty and COVID-19 risk factors: A rapid overview of interlinked deprivations across 5.7 Billion People, OPHI Briefing 53, Oxford Poverty and Human Development Initiative, University of Oxford

Al Sulais E, Mahmoud M, Al Ameel T (2020) The psychological impact of COVID 19-19 pandemic on physicians in Saudi Arabia: A cross-sectional study. Saudi J Gastroenterol 26(5):249. https:// doi.org/10.4103/sjg.SJG_174_20 
Alomo M, Gagliardi G, Peloche S, Somers E, Alzina P, Prokopez CR (2020) Efectos psicológicos de la pandemia COVID-19 en la población general de Argentina. Rev Fac Cienc Méd Córdoba 77(3):176-181. https://doi.org/10.31053/1853.0605.v77.n3.28561

Apple (2020) Informes de tendencias de movilidad. Retrieved January 8, 2021 from https://COVID-1919.apple.com/mobility

Appleton J (1975) The experience of landscape. Willey and Sons, London

Baillie R (2020) How social distancing has renewed our love for nature, and what it means for a sustainable future. Granite J 4(1):27-36

BADATA (2020) Casos COVID-19. Retrieved December 4, 2020 from https://data.buenosaires.gob.ar/dataset/casos-covid-19

Barrot JN, Grassi B, Sauvagnat J (2020) Sectoral effects of social distancing. HEC Paris Research Paper, FIN-2020-1371. https://doi. org/10.2139/ssrn.3569446

Beatley T (2011) Biophilic Cities: Integrating Nature into Urban Design and Planning. Island Pres. https://doi.org/10.5822/ 978-1-59726-986-5_3

Beatley T, Newman P (2013) Biophilic cities are sustainable, Resilient Cities. Sustainability 5. https://doi.org/10.3390/su5083328

Brooks SK, Webster RK, Smith LE, Woodland L, Wessely S, Greenberg N, Rubin GJ (2020) The psychological impact of confinement and how to reduce it: a rapid review of the evidence. Lancet 395(10227):912-920. https://doi.org/10.1016/S0140-6736(20) 30460-8

Camarotti AC, Jones D, Güelman M, Dulbecco P, Cunia S (2020) Cambios en los patrones de consumo de bebidas alcohólicas en la cuarentena por COVID-19-19. Un estudio en el Área Metropolitana de Buenos Aires (Argentina). Rev Salud Pública, edición especial 2. https://doi.org/10.31052/1853.1180.v.n

CDC (2017) Quarantine and Isolation. Retrieved December 5, 2020 from https://www.cdc.gov/quarantine/index.html

CDC (2020a) COVID-19-19 in racial and ethnic minority groups. Retrieved June 15, 2020 from https://www.cdc.gov/coronavirus/ 2019-ncov/needextra-precautions/racial-ethnic-minorities.html? deliveryName=USCDC_277-DM26455. Accessed 15 Jun 2020

CDC, Centers for Disease Control and Prevention - USA (2020b) Visiting parks and recreational facilities. Retrieved June 10, 2020 from https://www.cdc.gov/coronavirus/2019-ncov/dailylife-coping/visitors.html

Ceberio MR (2020) Psicólogos en el frente: la atención durante la crisis del COVID-19. De las emociones tóxicas a la salud psicológica. Arch de Med (Manizales) 21(1):225-237. https://doi.org/10. 30554/archmed.21.1.3941.2021

Chain DG (comp) (2009) Manual de Diseño Urbano. Gobierno de la Ciudad Autónoma de Buenos Aires, Subsecretaría de Proyectos de Urbanismo, Arquitectura e Infraestructura - Ministerio de Desarrollo Urbano. CABA

Cochran WG, Cox GN (1965) Diseños experimentales. Trollas, México

DNU 297 / 2020 and modifying clauses (2020) Poder Ejecutivo Nacional del Estado Argentino. Retrieved June 12, 2020 from https://www.argentina.gob.ar/normativa/nacional/decreto-2972020-335741/normas-modifican

Estadísticas GCBA (2019a) La pobreza multidimensional en la Ciudad de Buenos Aires. Año 2019. Retrieved May 2, 2020 from https:// www.estadisticaciudad.gob.ar/eyc/?p=50357

Estadísticas GCBA (2019b) Distribución porcentual de los hogares por personas por ambiente. Ciudad de Buenos Aires. Año 2008/2019. Retrieved December 4, 2020 from https://www.estadisticaciudad. gob.ar/eyc/wp-content/uploads/2021/02/ir_2021_1531.pdf

Faggi AM, Breuste N, Madanes N, Gropper C, Perelman P (2011) Water as an appreciated feature in the landscape: A comparison of residents and visitors preferences in Buenos Aires. J Clean Prod 19:1909-2132. https://doi.org/10.1016/j.jclepro.2011.09.009
Flaccus G (2020) Bird-watching soars amid COVID-19-19 as Americans head outdoors. AP News [Online]. Retrieved May 2, 2020 from https://apnews.com/article/94a1ea5938943d8a70fe794e9f629b13

Giallonardo V, Sampogna G, Del Vecchio V, Luciano M, Albert U, Carmassi C, Carrà G, Cirulli F, Dell'Osso B, Nanni MG, Pompili M, Sani G, Tortorella A, Volpe U, Fiorillo A (2020) The Impact of Quarantine and Physical Distancing Following COVID-19 on Mental Health: Study Protocol of a Multicentric Italian Population Trial. Front Psychiatry 11:533. https://doi.org/10.3389/fpsyt.2020.00533

Google (2021) Informe de movilidad de las comunidades ante el COVID-19-19, Argentina, Buenos Aires. Retrieved January 7, 2021 from https://www.gstatic.com/COVID-1919/mobility/202101-03_AR_Buenos_Aires_Mobility_Report_en.pdf

Groenewegen PP, Van den Berg AE, De Vries S, Verheij RA (2006) Vitamin G: effects of green space on health, well-being, and social safety. BMC Public Health 6:149. https://doi.org/10.1186/ 1471-2458-6-149

Guida Johnson B, Faggi A, Voigt A, Schnellinger J, Breuste J (2015) Environmental Perception among Residents of a Polluted Watershed in Buenos Aires. J Urban Plan Dev 141(3):A5014002

INDEC (2010) Censo Nacional de Población, Hogares y Viviendas 2010 Retrieved Fabruary 10, 2021 from https://redatam.indec. gob.ar/

Lustig N, Tommasi M (2020) El COVID-19 y la protección social de los grupos pobres y vulnerables en América Latina: un marco conceptual. Revista de la CEPAL No 132

Macri M, Lostri H, Chain D (2011) Modelo territorial: Buenos Aires 2010-2060. Ministerio de Desarrollo Urbano, Subsecretaría de Planeamiento. CABA

Madanes N, Faggi A, Perelman P (2013) Percepción directa y virtual del paisaje en el Parque Nacional Iguazú. Rev Asoc Argen Ecol De Paisajes 5:81-91

Maulan S, Shariff MK, Miller P (2006) Landscape preference and human survival well-being. ALAM CIPTA Intl J Sustain Trop Design Res Pract 1:24-31

National Academies of Sciences, Engineering, and Medicine (2020) Social Isolation and Loneliness in Older Adults: Opportunities for the Health Care System. Washington, DC: The National Academies Press. https://doi.org/10.17226/25663

OPHI (2020) Global Multidimensional Poverty INdex 2019: Illuminating Inequalities. Universidad de Oxford

Perelman PE, Marcon PL (2016) Percepción del verde urbano en parques de la ciudad de Buenos Aires. Multequina 25:1-10

Perelman P, Breuste J, Madanes N, Gropper Ch, Melignani E, Faggi A (2012) Use of visitors perception in urban reserves in the Buenos Aires metropolis. Urban Ecosyst 16(4):841-851. https://doi.org/ 10.1007/s11252-012-0279-7

Programa Buenos Aires Verde (2014) Los detalles del Plan Buenos Aires Verde. Retrieved May 5, 2020 from http://www.buenosaires. gob.ar/noticias/una-ciudad-mas-verde-es-una-ciudad-mas-abiertamoderna-y-saludable

Purcell AT, Lamb RJ (1998) Preference and naturalness: An ecological approach. Landsc Urban Plan 42(1):57-66

Samuelsson K, Barthel S, Colding J, Macassa G, Giusti M (2020) Urban nature as a source of resilience during social distancing amidst the coronavirus pandemic. OSF preprints. https://doi.org/ $10.31219 /$ osf.io/3wx5a

Saurabh K, Ranjan S (2020) Compliance and psychological impact of quarantine in children and adolescents due to Covid-19 pandemic. Indian J Pediatr 87:532-536. https://doi.org/10.1007/ s12098-020-03347-3

Schroeder H (2009) The Role of Imagination in Experiencing Natural Environments. In: Watts CE Jr, LeBlanc Fisher C (eds) Proceedings of the 2009 Northeastern Recreation Research Symposium, 
(pp 10-25) Gen. Tech. Rep. NRS-P-66. Newtown Square, PA: U.S. Department of Agriculture, Forest Service, Northern Research Station

Serafini G, Parmigiani B, Amerio A, Aguglia A, Sher L, Amore M (2020) The psychological impact of COVID-19 on the mental health in the general population. QJM Int J Med 113(8):531-537. https://doi.org/10.1093/qjmed/hcaa201

Shoari N, Ezzati M, Baumgartner J, Malacarne D, Fecht D (2020) Accessibility and allocation of public parks and gardens in England and Wales: A COVID-19-19 social distancing perspective. PLoS ONE 15(10):e0241102. https://doi.org/10.1371/journal. pone. 0241102

Slater SJ, Christiana RW, Gustat J (2020) Recommendations for keeping parks and green space accessible for mental and physical health during COVID-19 and other pandemics. Prev Chronic Dis 17:200204. https://doi.org/10.5888/pcd17.200204

Sorbara M, Graviotto HG, Lage-Ruiz GM, Turizo-Rodriguez CM, Sotelo-López LA, Serra A, Gagliardi C, Heinemann G, Martinez P, Ces-Magliano F, Serrano CM (2021) COVID-19 y la pandemia olvidada: el seguimiento de las enfermedades neurocognitivas durante la cuarentena en Argentina. Neurologia 36(1):9-15. https://doi.org/10.1016/j.nrl.2020.07.015

Tee ML, Tee CA, Anlacan JP, Aligam KJG, Reyes PWC, Kuruchittham V, Ho RC (2020) Psychological impact of COVID-19 pandemic in the Philippines. J Affect Disord 277:379-391. https://doi.org/ 10.1016/j.jad.2020.08.043

Ugolini F, Massetti L, Calaza-Martínez P, Cariñanos P, Dobbs C, Ostoić SK, Marin AM, Perlmutter D, Saaroni H, Šaulienė I, Simoneti M, Verlič A, Vuletić D, Sanesi G (2020) Effects of the COVID-19 pandemic on the use and perceptions of urban green space: An international exploratory study. Urban for Urban Green 56:126888. https://doi.org/10.1016/j.ufug.2020.126888
UNICEF (2019) The State of the World's Children 2019 Children, Food and Nutrition: Growing well in a changing world. UNICEF, New York

Van den Berg AE, Hartig T, Staats H (2007) Preference for nature in urbanized societies: Stress, restoration, and the pursuit of sustainability. J Soc Issues 63(1):79-96. https://doi.org/10.1111/j.15404560.2007.00497.x

Vazquez Brust A, Rodriguez L (2020) Atlas de Espacios Verdes en Ciudades Argentinas. Fundación Bunge y Born. Retrieved December 5, 2021 from https://www.fundacionbyb.org/atlas-espaciosverdes-argentina

Vlahov D, Freudenberg N, Proietti F, Ompad D, Quinn A, Nandi V, Galea S (2007) Urban as a determinant of health. J Urban Health 84(1):16-26. https://doi.org/10.1007/s11524-007-9169-3

Vouligny É, Domon G, Ruiz J (2009) An assessment of ordinary landscapes by an expert and by its residents: Landscape values in areas of intensive agricultural use. Land Use Policy 26(4):890-900. https://doi.org/10.1016/j.landusepol.2008.10.016

WHO, World Health Organization (2020) Immunity passports in the context of COVID-19. Available from: https://www.who.int/ news-room/commentaries/detail/immunity-passports-in-thecontext-of-covid-19

WHO, World Health Organization (2020) Brote de enfermedad por coronavirus (COVID-19). Retrieved February 20, 2021 from https:// www.who.int/es/emergencies/diseases/novel-coronavirus-2019

WHO, World Health Organization (2021) \#HealthyAtHome - Physical activity. Retrieved January 7, 2021 from https://www.who.int/ news-room/campaigns/connecting-the-world-to-combat-coronavirus/habealthyathome/habealthyathome---physical-activity

Yancy CW (2020) COVID-19 and African Americans. JAMA 323(19):1891-1892. https://doi.org/10.1001/jama.2020.6548 